\title{
Combating Unjustified Sanitary and Phytosanitary Measures in the African Tripartite Free Trade Area (SADC-EAC-COMESA): SPS-Plus or SPS-Minus?
}

\author{
HARRISON O. MBORI*
}

\begin{abstract}
Sanitary and phytosanitary measures (SPS) are incessant non-tariff barriers (NTBs) to trade in both intra and extra-African trade. New SPS measures are now set up in the African Tripartite Free Trade Area (TFTA) that amalgamate three existing regional economic communities (RECs): The Common Market for Eastern and Southern Africa (COMESA), the South African Development Community (SADC), and the East African Community (EAC).

This article compares and contrasts the SPS measures obligations as set out in Annex 15 of the TFTA to the WTO Agreement on the Application of Sanitary and Phytosanitary Measures (SPS Agreement). Additionally, the application of 'abusive SPS measures based on minority science' as non-tariff trade barriers to both internal and external African trade especially on agricultural products is analysed. An increase in transparency and accountability in the formulation of NTBs monitoring mechanisms in the COMESA, SADC, and EAC would address this ever present problem. The TFTA in Annex 15 is a case of SPS-Minus as it has a number of serious shortcomings including the lack of important obligations of sufficient risk assessment, non-discrimination, equivalence, the precautionary principle, and specific reference to consultations and dispute settlement. Notwithstanding these omissions, the TFTA has the potential for great achievement in the curbing of NTBs generally and unjustified SPS measures specifically because of the monitoring, transparency, and harmonisation obligations. If the Tripartite mandate, however, turns out to be like most other 'loose' integration efforts in Africa, then there is reason to believe that the NTB monitoring and reporting mechanism is not going to bear much fruit.
\end{abstract}

Keywords: Sanitary and Phytosanitary Measures (SPS), Tripartite Free Trade Agreement (TFTA), East Africa Community (EAC), South African Development Community (SADC), Common Market for Eastern and Southern Africa (COMESA), World Trade Organization (WTO)

\section{INTRODUCTION}

All states have a fundamental regulatory interest in protecting their human, animal, or plant health or life. ${ }^{1}$ This is an important and legitimate regulatory aim, at the [African] regional and domestic level but 'it rarely receives systematic and detailed attention in public debates and trade negotiations' ${ }^{2}$ and this is especially true as Africa regional integration has been described as 'loose' and 'flexible." ${ }^{3}$ This important and legitimate concern (protecting human, animal, and plant health or life) has to be counterbalanced with the general liberalisation aims of international trade. This is to ensure that these regulatory aims are not used as disguised protectionist measures to international trade. Marceau and Tratchman note, even with this noble aim in mind, that 'the distinction between a protectionist measure-

* Senior Research Fellow at Criminal Justice Research Department Lithuanian Law Institute tomas.rudzkis@teise.org. This thematic issue (Missed and new opportunities in world trade. Eds. Csongor István Nagy \& Zoltán Víg) was published as part of the research project of the HAS-Szeged Federal Markets 'Momentum' Research Group.

1 NicShuibhne (2006) 80; see also Alemanno (2007) 26.

2 Wagner (2017) 445-470.

3 Gathii (2010a) 608; see also Helfer (2012) 175-93. 
condemned for imposing discriminatory or unjustifiable costs, and a non-protectionist measure restriction trade incidentally (and thus imposing some costs), is difficult to make.'4 This is because 'free trade and regulatory autonomy are often at odds with each other.'

'The WTO is the most universal international trade body.' 6 The World Trade Organization's (WTO) multilateral legislative function has significantly waned in recent years. ${ }^{7}$ Focus, for both developing and developed countries, has now shifted to bilateral and regional trade agreements covering a myriad of substantive areas including investment, domestic regulation, and surprisingly, human rights. ${ }^{8}$ Two prominent examples in Africa are the just concluded Tripartite Free Trade Area (TFTA) amalgamating three existing regional economic communities (RECs): (the Common Market for Eastern and Southern Africa (COMESA), The Southern African Development Community (SADC), and the East African Community (EAC), and the Continental Free Trade Agreement (CFTA) seeking to bring the entire continent under one umbrella free trade agreement (FTA) which is still under negotiation.

Non-Tariff Measures (NTMs) are facially neutral governmental measures that may have an impact on trade. ${ }^{9}$ NTMs that act as prohibitions or restrictions on trade or NTMs that distort international trade without necessarily restricting it, are considered to be Nontariff barriers to trade (NTBs). ${ }^{10}$ The WTO Agreement on the Application of Sanitary and Phytosanitary Measures (SPS Agreement) ${ }^{11}$ and Agreement on Technical Barriers to Trade (TBT Agreement) ${ }^{12}$ were conceived as a response to the increasing importance of NTBs that had supplanted tariffs, as barriers to trade, in successive negotiation rounds of GATT before the formation of the WTO. ${ }^{13}$ Before the SPS Agreement entered into force, 'health regulations could only be justified once a prior violation of one of the GATT principles/ obligations had been found. ${ }^{14}$ The two agreements mentioned above were also conceived in pursuance of maintaining an appropriate balance between protectionist measures and allowing States to maintain their regulatory autonomy. ${ }^{15}$

This article therefore investigates the SPS measures under the African TFTA and under the various RECs that constitute the TFTA. This analysis compares and contrasts these SPS measures to the WTO SPS Agreement. The article is divided into two broad parts. The first part an introduction to the African TFTA, describing its nature, origin, and geographic coverage. This part also discusses the legal regime on SPS measures in the Southern Africa Development Community (SADC), the East African Community (EAC), and Common

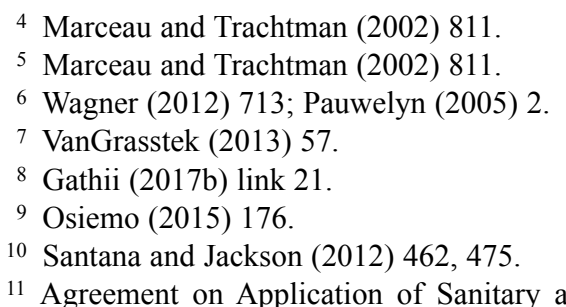
Agreement, Annex 1A, Legal Instruments-Results of the Uruguay Round, 69.

12 Agreement on Technical to Barriers to Trade, 15 April 1994, Marrakesh Agreement Establishing the World Trade Organization, Annex 1A, Legal Instruments - Results of the Uruguay Round, vol. 31, 138.

13 Ahearn and Fergusson (2010) 3.

14 Pauwelyn (1999a) 644.

15 Marceau and Trachtman (2002). 
Market of Eastern and Southern Africa (COMESA). The second and final part focuses on Annex 15 of the TFTA covering its SPS provisions and how they compare with the SPS provisions of the three different RECs. This part also offers recommendations and asserts that SPSs are one of the major NTBs that should be addressed in both intra and extra-Africa trade and that the measures proposed for monitoring and reporting NTBs should be more transparent and accountable to enhance their legitimacy and assist in the elimination of NTBs. It is generally argued that, due to the intertwining nature of memberships in the different RECs (spaghetti bowl), the efforts at streamlining the process of monitoring, reporting, and eradication of NTBs in intra-African trade may be compromised.

\section{THE TRIPARTITE FREE TRADE AREA: FROM CAPE TOWN-TO-CAIRO}

The COMESA-SADC-EAC Tripartite Free Trade Area (TFTA) amalgamates three existing Regional Economic Communities (RECs): the Eastern Africa Community (EAC), ${ }^{16}$ the Common Market for Eastern and Southern Africa (COMESA), ${ }^{17}$ and the Southern African Development Community (SADC). ${ }^{18}$ The TFTA was first conceived in 2005 and the Tripartite Task Force, headed by the Secretary Generals of the three RECs have met at least twice per year since $2006 .{ }^{19}$ On $15^{\text {th }}$ June 2015, the COMESA-EAC-SADC Tripartite Free Trade Area (TFTA) was launched in the Egyptian resort of Sharm El Sheik by the 26 member States. ${ }^{20}$ The TFTA covers a population of 632 million and a combined GDP of $\$ 1.3$ trillion. ${ }^{21}$ It covers an area that spans 17.3 million square kilometers; nearly twice the size of China or the United States and will represent more people than the North American Free Trade Area (NAFTA) or the European Union. ${ }^{22}$ The overarching objective of the Tripartite Free Trade Area is to contribute to the broader objectives of the African Union

16 The Treaty Establishing the East Africa Community (EAC) was signed on 30 November 1999 and entered into force on 7 July 2000. Its original members were Kenya, Tanzania, and Uganda. Burundi and Rwanda acceded to the EAC Treaty on 18 June 2007 and became full members on 1 July 2007. The Republic of South Sudan acceded to the Treaty on 15 April 2016 and become a full Member on 15 August 2016.

17 The Common Market for Eastern and Southern Africa (COMESA) was formed on 8 December 1994. It replaced the former Preferential Trade Area (PTA) which had been in existence since 1981, with the objective of ultimately creating a larger market for greater social and economic cooperation between members and eventually resulting in a common market. The COMESA Treaty was signed on 5 November 1993 in Kampala, Uganda and later ratified on 8 December 1994. Its current members are Burundi, Comoros, the Democratic Republic of Congo (DRC), Djibouti, Egypt, Eritrea, Ethiopia, Kenya, Libya, Madagascar, Malawi, Mauritius, Rwanda, Seychelles, South Sudan, Sudan, Swaziland, Uganda, Zambia, and Zimbabwe.

18 The Southern African Development Community (SADC) was formed in 1980 with 9 Member States, as the Southern African Development Coordination Conference (SADCC). The SADCC was formed after the adoption of the Lusaka Declaration-Southern Africa: Towards Economic Liberationin 1980. The founding Member States were Angola, Botswana, Lesotho, Malawi, Mozambique, Swaziland, Tanzania, Zambia and Zimbabwe.

19 East African Community (COMESA-EAC-SADC) Tripartite (2017) Link 6.

20 SADC, COMESA, EAC-SADC Tripartite Free Trade Area Launched, Link 15. The TFTA will stretch from Cape Town to Cairo, creating an integrated market with a combined population of almost 600 million and a total Gross Domestic Product (GDP) of about US\$ 1 trillion.

21 Juma, Mageni (2017) link 2.

22 Bird (2017) link 11. 
(AU) - The acceleration of economic integration of the continent and achieving sustainable development, alleviating poverty and improving the quality of life for the people of the eastern, central, and southern African Region. ${ }^{23}$

It is important to note that the TFTA is not an attempt to merge COMESA, SADC, and the EAC at their current integration levels. ${ }^{24}$ It is instead intended that the already existing FTAs under the various RECs would form a wider FTA encompassing the 26 countries.

\subsection{SPS Measures Existing under in SADC, EAC, and COMESA}

The three RECs that form part of the TFTA had already set up their own individual SPS measures before the conclusion of the TFTA and launch them in 2015. SADC member states negotiated and adopted the SADC Trade Protocol (SACD PT) from which Annex VIII concerning Sanitary and Phytosanitary Measures was adopted. EAC member states also negotiated and adopted the EAC Protocol on Sanitary and Phytosanitary measures pursuant to Article 108 of the EAC Treaty, ${ }^{25}$ and Article 38 of the Protocol on the Establishment of the East African Customs Union. ${ }^{26}$ Both these provisions require the harmonisation and co-operation of the EAC member states regarding the application of SPS measures in the establishment of the EAC as an economic community and as a customs union. The COMESA member states undertook through the COMESA SPS Regulations, which were adopted as part of the legal framework of the COMESA Treaty, to implement and harmonise their SPS measures. This is the general backdrop upon which the TFTA negotiations were being undertaken about SPS measures. The biggest concern would therefore be the direct duplication, overlap, and contradiction of obligations horizontally among the RECs and vertically with the WTO SPS Agreement. SADC member states were the first to set up their SPS regime in 2000, followed by COMESA member states in 2009 and lastly EAC member states in 2016. The following section analyses more specifically the three different and separate SPS regimes and compares them to the WTO SPS Agreement.

\subsubsection{An Assessment of the SADC SPS Annex VIII}

The SADC Trade Protocol (SADC-PT) was passed on $24^{\text {th }}$ August $1996 .{ }^{27}$ It only came into effect on $1^{\text {st }}$ September 2000 after protracted negotiations. ${ }^{28}$ The SADC-PT, according to the SADC Treaty, ${ }^{29}$ is 'an instrument of implementation' carrying the same legal force as the SADC treaty. The SADC-PT has the objectives of further liberalisation of intraregional trade in goods and services; ensuring efficient production within SADC; contributing towards improvement of the climate for domestic, cross-border and foreign investment; enhancing the economic development, diversification and industrialisation of the region; and establishing a Free Trade Area (FTA) in the SADC region. ${ }^{30}$ Article 16 of the Protocol provides the main obligations on SPS measures. SADC member states agree to

${ }^{23}$ East African Community (COMESA-EAC-SADC) Tripartite (2017) link 6.

${ }^{24}$ Kalenga (2011) link 9.

25 The Treaty for the Establishment of the East African Community (As amended on 14th December 2006 and 20th August 2007).

26 The Protocol on the Establishment of the East African Customs Union (2005) link 14.

27 SADC (2017) link 15.

28 Kalenga (2004) link 13.

29 Treaty of the Southern African Development Community (SADC), 32 ILM 116, Article 1.

30 Southern African Development Community, (1996), SADC Protocol on Trade, Article 2. 
base their SPS measures on international standards, guidelines, and recommendations in order to harmonise sanitary and phytosanitary measures for agriculture and livestock production. ${ }^{31}$ Additionally, the provision also obliges SADC member states, upon request, to enter into consultation with the aim of achieving agreements on recognition of the equivalence of specific sanitary and phytosanitary measures, in accordance with the WTO SPS Agreement. ${ }^{32}$ The SADC SPS Annex was signed on $7^{\text {th }}$ December 2012 and came into force upon approval by the SADC Committee of Ministers of Trade on $17^{\text {th }}$ July 2014, in Gaborone, Botswana. ${ }^{33}$

It is important to note that all the member states of SADC are also members of the WTO. This means that the multilateral obligations stemming from the WTO SPS Agreement apply to them even without the more specific obligations in the SADC-PT and Annex VIII. The objectives of Annex VIII are to facilitate the protection of human, animal or plant life or health in the territory of members; to enhance the member states' implementation of the WTO SPS Agreement; to enhance technical capacity to implement and monitor SPS measures including promoting greater use of international standards and other matters concerning SPS; to provide a regional forum for addressing sanitary and phytosanitary matters and to provide a regional forum for resolving trade related sanitary and phytosanitary issues. ${ }^{34}$ As emphasised in the second objective of the SADC-PT, the majority of provisions in the Protocol correspond directly with those in the WTO SPS Agreement. Additionally, it is important to note that Annex VIII has two appendices, the 'Transparency of Sanitary and Phytosanitary Regulations' (Appendix A) and 'Control Inspection and Approval Procedures' (Appendix B). These two appendices form an integral part of the SADC Annex and the SADC-PT on trade. ${ }^{35}$

The core substantive provisions of the SADC-SPS Annex are largely identical in wording and in purpose to the WTO SPS Agreement. ${ }^{36}$ There are, however, certain specific differences and variances that might have serious legal implications. On the principle of harmonisation, the SADC member states undertook 'where appropriate' to work towards harmonisation of their respective mandatory requirements taking into account relevant international standards, guidelines or recommendations. ${ }^{37}$ The wording here is at variance with that of the WTO SPS Agreement which requires that members 'base their sanitary or phytosanitary measures on international standards, guidelines, and recommendations. 38 The use of the word 'taking into account relevant' international standards in the SADC-SPS is less stringent than 'based on' international standard in the WTO SPS Agreement. This is based on the WTO Appellate Body's view on the establishment of a presumption of consistency when measures are based on international standards. ${ }^{39}$ This means that SADC member states need not base their SPS measures on international standards if they have taken into account relevant international standards. This is accurate for at least the SADC SPS standards even though all SADC members are WTO members and are therefore bound

31 SADC Protocol on Trade, Article 16(1).

32 SADC Protocol on Trade, 16(2).

33 Joubert (2014) 26.

34 SADC-PT, Article 2.

35 SADC-PT, Article 4.

36 Joubert (2014) 27.

37 SADC-SPS Annex, Article 6(1).

38 WTO SPS Agreement, Article 3(1).

39 Appellate Body Report on EC-Hormones, para 171. 
by the higher WTO SPS Agreement standard. Additionally, SADC member states are required within the limits of their resources to make every effort to participate in relevant international organisations and, whenever possible, if mandated, to present a common SADC position in these organisations to promote within these organisations the development of periodic review of standards, guidelines, and recommendations with respect to sanitary and phytosanitary measures. ${ }^{40}$

The next substantive requirement is equivalence. SADC members undertake to the extent practicable, without compromising their appropriate levels of SPS protection and in accordance with guidelines developed by the WTO SPS Committee and the relevant international standard setting bodies, to enter into consultations aimed at achieving bilateral or regional agreements on the recognition of equivalence of their SPS measures. ${ }^{41}$ This provision is more extensively worded than that of the WTO SPS Agreement. ${ }^{42}$ Both instruments, however, use the mandatory phrase; 'shall accept' the SPS measures of other member states as equivalent. This accordingly means that members have no discretion to refuse requests of the equivalence recognition once the inspection, test, and relevant procedures have been met. ${ }^{43} \mathrm{An}$ objective assessment by the importing member state and the exporting member state provided the importing member state provides scientific evidence or other information, in accordance with risk assessment methodologies agreed upon by both members. ${ }^{44}$ If an importing member state on a scientific basis determines that the exporting member state's SPS measures does not achieve the importing member's level of protection, then it may refuse to accept the SPS measures as equivalent. ${ }^{45}$ Written reasons should be provided in case of such refusal. ${ }^{46}$ It is important to note that the SADC-SPS obligation on equivalence should be read similarly, based on the language of Annex VIII, on the requirement of the WTO SPS Agreement that does not require 'duplication or sameness' of the measures, but 'the alternative' of the measure if objectively and scientifically proven should be acceptable. ${ }^{47}$

Additionally, Annex VIII also has the core substantive provisions of risk assessment and determination of the appropriate level of SPS protection..$^{48}$ In making this assessment of risk, members are required to take into account various factors including relevant scientific evidence. ${ }^{49}$ This provision is similarly present in the WTO SPS Agreement which requires members to base their SPS measures on relevant scientific evidence as described in Article 2 and 5 of the WTO SPS Agreement. This means that the SADC members are committed to taking a science-based approach when it comes to the imposition of SPS measures. This is true, as seen above, even in the equivalence provisions. SADC members are required to base their SPS measures, on an assessment and as appropriate to the circumstance of the risk to human, animal and plant life or health. ${ }^{50}$ These risk assessment, like that in the WTO

40 SADC-SPS Annex, Article 6(2).

41 SADC-SPS Annex, Article 7(1).

42 Compare SADC-SPS Annex, Article 7(2) to WTO SPS Agreement, Article 4.

43 Landwehr (2007) 433.

44 SADC-SPS Annex, Article 7(2) (a).

45 SADC-SPS Annex, Article 7(2) (b).

46 SADC-SPS Annex, Article 7(2) (c).

47 SPS Committee (2004) 1.

48 SADC-SPS Annex, Article 8.

49 SADC SPS Annex, Article 8(2).

50 SADC SPS Annex, Article 8(2). 
SPS Agreement, should 'be based on scientific principles. ${ }^{51}$ Furthermore, SADC members have undertaken to follow international standards in developing their SPS measures. ${ }^{52}$ Importantly, Annex VIII embodies the precautionary principle. SADC member states can depart from the strictures of risk assessment, when such a member state determines that the available relevant scientific evidence or other information is insufficient to complete the assessment. ${ }^{53}$ Such a member state may adopt a provisional SPS measure on the basis of available relevant information including from international standardising organizations and from SPS measures of other member states. ${ }^{54}$

Another key feature in the regulation of SPS measures is the precautionary principle. The principle made its first appearance in 1992 in environmental law under Principle 15 of the Rio Declaration. ${ }^{55}$ In international trade, the principle was introduced in Article 5.7 of the SPS Agreement as a component of risk management. ${ }^{56}$ The precautionary principle is important where parties are unable to make an objective risk assessment, thus striking a balance between international trade liberalisation and public health protection. ${ }^{57}$ It has the effect of allowing members to maintain provisional SPS measures where the relevant scientific evidence is insufficient. ${ }^{58}$ Thus, a positive action, such as a ban, may be adopted before the existence of a risk is scientifically established..$^{59}$ The provisional measure must be adopted on the basis of relevant information. ${ }^{60}$ The provision on precautionary principle under the SADC SPS Annex corresponds almost directly to the WTO SPS Agreement provision on the same. The purpose of the provision is the same while the wording is slightly different. The SADC SPS allows parties to maintain a provisional measure, on the basis of available relevant information, in cases where there is insufficient scientific information to conduct a risk assessment. ${ }^{61}$ There is a further requirement that members should, while applying the provisional measure, seek to obtain the additional information necessary to conduct an objective risk assessment. ${ }^{62}$ They are also required to review the provisional measure within a reasonable period of time. ${ }^{63}$ The similarity of this provision with the WTO SPS provision on the precautionary principle prevents any contradiction on the responsibilities of Member States according to the SADC SPS Annex and the WTO SPS Agreement. It instead has the requirement of streamlining regulation of SPS measures within the SADC SPS regime and the WTO SPS regime.

Furthermore, special and differential treatment is a principle that seeks to take into account the unique needs of developing and least developing countries, granting them favourable treatment in trade so as to increase their capacity to participate in in the global trading system. ${ }^{64}$ It aims to ensure that developing and least developing countries

51 SADC SPS Annex, Article 8(2); compare WTO SPS Agreement, Article 5(1) \& (2).

52 SADC SPS Annex, Article 8(1).

53 SADC SPS Annex, Article 8(1), Article 8(3); compare WTO SPS Agreement, Article 5(7).

54 SADC SPS Annex, Article 8(3).

55 Laowonsiri (2010) 569.

56 Laowonsiri (2010) 569.

57 Laowonsiri (2010) 567.

58 SADC SPS Annex, Article 8 (3); WTO SPS Agreement, Article 5 (7).

59 SADC SPS Annex, Article 8 (3); WTO SPS Agreement, Article 5 (7).

60 SADC SPS Annex, Article 8 (3).

61 SADC SPS Annex, Article 8 (3).

62 SADC SPS Annex, Article 8 (3).

63 SADC SPS Annex, Article 8 (3).

64 Brennan (2011) 143. 
participate on a proportionately beneficial basis by going beyond formal guarantees of equality. ${ }^{65}$ Special and differential treatment is not limited to tariffs but also extends to nontariff issues such as extended time-frames of implementation, exemptions and flexibility from certain rules and technical assistance. ${ }^{66}$ The WTO SPS Agreement provides for special and differential treatment in favour of developing countries and least-developed countries (LDCs). It includes, under certain circumstances, longer time-frames for compliance, timelimited exceptions from the obligations of the Agreement and facilitation of developing country participation in the work of the relevant international organisations. ${ }^{67}$ The participation of developing and least develop countries in the work of relevant international organisations is to ensure that there is equality and broader representation of their needs and interests within these international organisations. ${ }^{68}$ The WTO SPS Agreement also provides for technical assistance to Members, especially developing country Members. ${ }^{69}$ The SADC SPS Annex, unlike the WTO SPS Agreement, has no provisions on special and differential treatment. This could be due to the members of SADC being either developing or least developed countries themselves or special or differential obligations were never negotiated by the least developed of SADC member states. The SADC SPS Annex, however, makes provisions for technical assistance to enhance the capacity of Member States to implement and monitor sanitary and phytosanitary measures. ${ }^{70}$ Resource mobilisation for technical assistance under the SADC SPS Annex is a mandate to be facilitated by the SADC Secretariat working together with the SADC Sanitary and Phytosanitary Coordinating Committee. The WTO SPS Agreement, unlike the SADC SPS Annex, mandates the Members themselves to facilitate resource mobilisation for technical assistance. $^{71}$

In an effort to ensure transparency of sanitary and phytosanitary measures, the SADC SPS Annex requires each Member State to ensure that a WTO SPS Enquiry Point exists. ${ }^{72}$ The enquiry point has the mandate of providing answers to all questions from interested Member States on matters SPS. ${ }^{73}$ The WTO SPS Agreement similarly requires the establishment of enquiry points to achieve the same mandate. ${ }^{74}$ The recognition of the WTO SPS Enquiry Point by the SADC SPS Annex is important as it defeats the possibility of dual institutions conducting the same functions. Angola, Botswana, Lesotho, Madagascar, Malawi, Mauritius, Mozambique, Namibia, Seychelles, South Africa, Swaziland, Tanzania, Zambia, and Zimbabwe have established national notification and enquiry points. ${ }^{75}$ The SADC SPS Annex does not mandate Member States to establish new enquiry points. Instead, it recognises the WTO SPS Enquiry Points and seeks to harmonise the functions between the different agreements. Closely related to the management of SPS measures is

65 Brennan (2011) 143.

${ }^{66}$ Committee on Trade and Development (2001).

67 SADC SPS Annex, Article 10.

68 Seibert-Fohr (2007) 510.

69 SADC SPS Annex, Article 9.

70 SADC SPS Annex, Article 12.

71 WTO SPS Agreement, Article 9.

72 SADC SPS Annex Appendix A, Article 3.

73 SADC SPS Annex Appendix A, Article 3.

74 Article 3, Annex B, WTO SPS Agreement.

75 Gebrehwet, Ngqangweni and Kirsten (2007) 1. 
the SPS Committee. The WTO SPS Agreement establishes the Committee on Sanitary and Phytosanitary Measures (SPS Committee) to act as the main administration unit of the Agreement to oversee its implementation. ${ }^{76}$ The SPS Committee is a regular forum at the WTO where member States and governments with observer status can conduct consultations about SPS measures that affect trade to oversee the implementation of the WTO SPS Agreement. Article 14 of the SADC SPS Annex establishes the SADC Sanitary and Phytosanitary Coordinating Committee. It also requires each member state to establish a National Committee on Sanitary and Phytosanitary measures. ${ }^{77}$ The SADC SPS Coordinating Committee then compromises of two representatives of each National Committee on Sanitary and Phytosanitary Measures. ${ }^{78}$ The SADC SPS Coordinating Committee acts as a consultative forum for promoting the objectives of the SADC SPS Annex and strengthening cooperation between regulatory agencies. ${ }^{79}$ It is also mandated to promote transparency in SPS measures. ${ }^{80}$

\subsubsection{An Assessment of the East African Community Sanitary \& Phytosanitary Measures Protocol}

The EAC has a current membership of 6 partner states, with the latest entrant being South Sudan. Article 5(2) of the Treaty establishing the East African Community states that the first stage of EAC integration will be the formation of a customs union. ${ }^{81}$ The EAC Customs Union Protocol came into force in January 2005. The Protocol has four major elements within its primary objective of facilitating intra and inter African trade, the fourth of which is the elimination of non-tariff barriers (NTBs). ${ }^{82}$ Article 38 of the Customs Union Protocol requires partner states to take cognizance of cooperation in sanitary and phytosanitary measures in order to facilitate trade in the community and among other trading partners. ${ }^{83}$ The legal basis for the EAC SPS Protocol was also derived from the EAC Common Market Protocol in Article 5(2) (a), ${ }^{84}$ which requires that the partner states are to harmonise and mutually recognise SPS standards and technical barriers to trade. The East African Communities Sanitary and Phytosanitary Measures Protocol that entered into force on $12^{\text {th }}$ July 2013, provides the legal basis for reforms in the EAC that are to guarantee food safety, plant protection and animal health. ${ }^{85}$ The Protocol came about pursuant to Article $151^{86}$ of the EAC treaty that states that partner states may conclude such protocols as may be necessary for the area of cooperation and Articles 105 to 110 of the EAC Treaty which provides for partner states to cooperate in agriculture and food safety.

76 Gebrehwet, Ngqangweni and Kirsten (2007) 1. WTO Sanitary and Phytosanitary Agreement (1995), Article 12. The SPS Committee has been involved in the reviewing of the SPS Agreement since its inception.

77 SADC SPS Annex, Article 14 (2).

78 SADC SPS Annex, Article 14 (1).

79 SADC SPS Annex, Article 14 (5).

80 SADC SPS Annex, Article 14 (4).

81 Treaty establishing the East African Community, Amended (2007), Article 5(2).

82 East African Community Customs Union Protocol, 2005.

83 East African Customs Union Protocol, 2005, Article 38.

${ }^{84}$ East African Community Common Market Protocol, 2010, Article 5(2) (a).

85 Kenya's Ratification (2016) link 10.

86 Treaty establishing the East African Community, Amended (2007), Article 151. 
A reading of the objectives of the EAC Sanitary and Phytosanitary Protocol ('The EAC SPS Protocol') leads to a prima facie conclusion that it largely mirrors the WTO SPS Agreement, in that most of its provisions are borrowed lock, stock, and barrel from the WTO SPS agreement. ${ }^{87}$ The preamble of the EAC SPS Protocol takes note of the principle of harmonisation, for the improvement of human, animal and plant health life; the importance of the security and safety and free trade in agricultural products and, most importantly, the importance of maintaining international standards and guidelines in the formulation of SPS regulations. ${ }^{88}$ The EAC SPS Protocol is primarily similar to the provisions of the WTO SPS agreement and serves in many areas such as risk mitigation, transparency, coordination and harmonisation of laws to bring to life the provisions of the SPS Agreement. This is in the exception of some of the principles such as nondiscrimination, equivalence and risk assessment that have not been adequately addressed in the EAC SPS Protocol. ${ }^{89}$ The Protocol is, however, substantially in conformity with the provisions of the WTO SPS Agreement and that it serves to guarantee of better food safety measures; mitigation of risks from pests and diseases and improved competitiveness of produce of the EAC in relation to external markets. ${ }^{90}$ The EAC has been known to have focused its efforts to harmonise SPS measures and common interests through various working groups. ${ }^{91}$

The WTO SPS Agreement, amongst other things, enunciates the principles of nondiscrimination, transparency, harmonisation of laws and regulations, international standards and special and differential treatment to developing countries. ${ }^{92}$ It is to be noted that all of the members of the EAC, except South Sudan, are also members of the WTO and therefore are bound to the provisions of the WTO SPS Agreement. It is recognised, however, that even though the WTO SPS Agreement was an attempt to have a harmonized multilateral system of SPS measures, it noted in its preamble that these measures are often applied on the basis of bilateral agreements or protocols. The only given caveat is that when members apply measures to protect their animal plant health or food safety, that these should not constitute arbitrary or unjustifiable discrimination or disguised restriction on international trade. ${ }^{93}$

Article 2 of the EAC SPS Protocol to begin with, describes its objectives as promoting trade of food and agricultural products within the community through the implementation on principles of harmonisation, transparency, risk assessment, and strengthening the coordination of SPS measures and activities at a national and regional level within the community. ${ }^{94}$ In this, it is stated that partner states shall cooperate in the harmonisation of laws and regulations. This part is in line with Article 3 of the WTO SPS Agreement ${ }^{95}$ which provides for harmonisation. Here, the SPS Agreement requires that the members base their SPS recommendations on international standards and guidelines as widely as possible. It should be noted that the provisions of the EAC SPS Protocol do not expressly

87 USAID (2016).

${ }^{88}$ East African Community Sanitary and Phytosanitary Measures Protocol (2013) Preamble.

89 Prévost (2010).

90 East Africa Trade and Investment Hub (2016) link 7.

91 Magalhães (2010).

92 WTO Sanitary and Phytosanitary Agreement (1995) Preamble.

93 WTO SPS Agreement (1995) Preamble; Article 1.

94 East African Community Sanitary and Phytosanitary Measures Protocol (2013) Article 2.

95 WTO SPS Agreement (1995) Article 3. 
include the important aspect of basing the laws and regulations on international standards, but only states that the approach to be used shall be science-based and that there shall be a common understanding between the parties. ${ }^{96}$ This is seen, according to the author, as a significant shortfall, in that even though the requirement of harmonisation is present, it is not expressly stated in the language given in the WTO SPS Agreement which seems to be more wide-ranging.

Article $4^{97}$ which discusses plant health, states that the partner states are to among other things, harmonise the inspection of certification procedures of plant and plant products, regulate the development and use of modified organisms and products of biological modification, provide a framework for management, build systems for surveillance in pest risk analysis, designation of pest-free areas and the areas of low prevalence and harmonise import and export procedures which include the registration and identification of plant and plant products. ${ }^{98}$ This part is seen predominantly to be in conformity with Articles 3, 5, 6, and 8 of the WTO SPS Agreement; however, it should be noted that the prospects of risk assessment (Article 5) have not been adequately laid out in the EAC SPS Protocol as extensively as they have in the WTO SPS Agreement. ${ }^{99}$ Article 5 requires that the SPS measures be based on assessment of the risks to human, animal and plant health life based on assessment techniques in international standards and in cognizance of economic factors and scientific evidence. ${ }^{100}$ The provisions of the EAC SPS Protocol are therefore seen as somewhat of a shortfall, especially because it is only noted that there shall be surveillance in risk analysis. There is no mention as to whether risk assessment shall be pegged on scientific evidence - an issue that has been substantially controversial in this topic. $^{101}$

On matters of animal health, Article 5 posits that the partner states shall provide prompt and transparent notification of the existence of animal diseases, including the sharing of information on the trade sensitive diseases as well as the identification of infected zones. ${ }^{102}$ It further goes to state in Article 5(2) (b) that there shall be the harmonisation of the inspection, certification and approval of butcheries, feed centres, dairies, animal products and feed stuff. ${ }^{103}$ It demands amongst others, that there be a standardisation of sanitary documents including import tariffs and veterinary certificates and similar to that in plant health, it requires a harmonisation of systems for registration, identification and traceability of animals and animal products. This part is in conformity to the WTO SPS Agreement provisions in Article 3, 6, 7 and 8. Article 7 of the SPS Agreement states that members shall notify all others of any changes in their SPS measures. The EAC SPS protocol stresses that there should be the sharing of information which is also in accordance with Article 9 of the WTO SPS Agreement on the sharing of information.

\footnotetext{
96 Magalhães (2012) 12.

97 East African Community Sanitary and Phytosanitary Measures Protocol (2013) Article 4.

98 East African Community Sanitary and Phytosanitary Measures Protocol (2013) Article 4.

99 WTO SPS Agreement (1995) Article 5.

100 Magalhães (2012) 12.

101 East Africa Trade and Investment Hub (2016) link 7.

102 East African Community Sanitary and Phytosanitary Measures Protocol (2013) Article 5.

103 East African Community Sanitary and Phytosanitary Measures Protocol (2013) Article
} 5 (2) (b). 
The provisions of Article 6 speak of food safety stipulating that partner states shall harmonize food inspection, certification and approval procedures, safety requirements for food coming from genetically modified organisms, surveillance systems for food-borne hazards in the community, import requirements and food traceability systems. There should also be the harmonisation of the determination of tolerance levels for additives, contaminants and toxins. The provisions of this part are also predominantly in conformity to Articles 3, 6, 7 and 8 of the WTO SPS Agreement and once again go to show that the principle of harmonisation has been adequately catered for in the EAC SPS Agreement.

The other provisions of the agreement stipulate other important principles stipulated in the WTO SPS Agreement. ${ }^{104}$ In Article 7, Partner states are to designate competent authorities for the purposes of the protocol, while Article 8 elaborates extensively on Border Posts Control. Here, the protocol provides that there shall be the smooth movement of food and agricultural commodities within the region, joint inspection and clearance of food and agricultural commodities. ${ }^{105}$ Article 8 of the WTO SPS agreement speaks of control, inspection and approval procedures and primarily posits that the members shall ensure that their procedures are consistent with Annex $\mathrm{C}$ to the Agreement and with all the provisions of the agreement.

In accordance with the SPS Agreement provisions on sharing of information, the protocol provides in Article $9^{106}$ that there shall be cooperation of the sharing of information and expertise on SPS measures through the establishment of a regional information management system and that the states shall also jointly seek technical assistance in this and this is in accordance to Article 9 of the WTO SPS Agreement. ${ }^{107}$ Most importantly, Article 11 then requires that the partner states harmonise their policies, laws and programs, which is in line with Article 3 of the WTO SPS Agreement. ${ }^{108}$

On dispute settlement, Article 14 states that any disputes arising between the parties should be settled in accordance with the provisions of the EAC treaty. Article 11 of the WTO SPS Agreement, although noting that Articles XXII and XXIII of the GATT 1994 apply in disputes under the agreement, states in 11(3) that nothing shall impair the rights of members under other international agreements. ${ }^{109}$ It is to be noted that the provisions of dispute settlement may be confusing in some way, as alluded to by Magalhães, who argues that the redrafting of some of the articles of the WTO SPS Agreement may lead to confusion for instance in Article 14 on dispute settlement. ${ }^{110}$

As seen under the SADC SPS regime, the provisions on Special and Differential Treatment are notably absent under the EAC SPS Protocol. ${ }^{111}$ This can, however, be partly explained by the fact that the EAC is entirely made up of developing and least developing states, which are deemed to be on the same level of development according to a 2014 report by UNCTAD. ${ }^{112}$ This, however, begs the question what recourse a state such as South

104 These are such as the sharing of information, inspection procedures of the various animal/ plant health life and dispute settlement among others.

105 East African Community Sanitary and Phytosanitary Measures Protocol (2013) Article 7.

106 East African Community Sanitary and Phytosanitary Measures Protocol (2013).

107 East African Community Sanitary and Phytosanitary Measures Protocol (2013), See Article 9; Magalhães (2012).

108 East African Community Sanitary and Phytosanitary Measures Protocol, 2013, Article 11.

109 WTO SPS Agreement (1995) Article 11(3).

110 Magalhães (2010) 13.

111 WTO SPS Agreement (1995) Article 10.

112 UNCTAD (2014) 146. 
Sudan would have since it is classified as a least developed country. ${ }^{113}$ Article 10 of the WTO SPS Agreement states that members shall take into account the needs of developing and least developed members among them in the application and preparation of SPS measures. In this, for instance, longer time frames for compliance should be accorded to such partner states to maintain opportunities for their exports. ${ }^{114}$ The EAC SPS Protocol does not have anything in relation to special and differential treatment; this can be arguably seen as a shortfall.

\subsubsection{An Assessment of COMESA SPS Measures}

COMESA, as of October 2017, has nineteen member states. ${ }^{115}$ It is important to note that this membership does not include the Republic of South Africa and the Republic of Botswana, the two hegemons in Southern Africa. Somalia in the East is also not a member of COMESA. Additionally, among the COMESA member states, the following are not member states of the WTO: The Union of Comoros, ${ }^{116}$ Eritrea, Ethiopia, Libya, and Sudan and despite their nonmembership, Ethiopia, Sudan, and Libya are observer governments in the WTO. ${ }^{117}$

Article 10 of the Treaty establishing the Common Market for Eastern \& Southern Africa (COMESA Treaty) ${ }^{118}$ vests the COMESA Council of Ministers ${ }^{119}$ with the power to make regulations, issue directives, take decisions and make recommendations or deliver opinions. The provision goes further to stipulate that a regulation shall be binding on all the member states in its entirety, a directive shall be binding upon each member state to which it is addressed as the result to be achieved but not as to the means of achieving it, a decision shall be binding upon those to whom it is addressed, and a recommendation and an opinion shall have no binding force. ${ }^{120}$ The meaning of the absolute binding nature of COMESA regulations has been clarified by the Legal Office of COMESA Secretariat as:

'As for what it means when it says 'a regulation shall be binding in its entirety', it simply means that all provisions of the regulation are mandatory and Member States are required to comply with them. It also means that a regulation is directly applicable and a Member State using its own procedures has to ensure that it is domesticated. In some countries it does not need to be ratified. In some countries it needs to be ratified as a matter of course since it is already binding on the Member States by virtue of the Authority of the Treaty' ${ }^{\prime 21}$

113 Prévost (2010).

114 WTO SPS Agreement (1995) Article 10.

115 COMESA (2017) link 4.

116 The Union of Comoros is, however, in the process of acceding to the WTO and intends to complete the process by MC11 in December 2017 in Buenos Aires Argentina.

117 WTO (2017) link 22.

118 Treaty establishing the Common Market for Eastern \& Southern Africa 33 ILM 1067 (1994) (COMESA Treaty).

119 The Council of Ministers is established under Article 7 of the COMESA treaty together with the COMESA Authority, the Court of Justice, the Committee of Governors of Central Banks, the Intergovernmental Committee, the Technical Committee, the Secretariat, and the Consultative Committee.

120 COMESA Treaty, Article 10(2), (3), (4), \& (5).

121 Ravelomanantsoa (2012). 


\subsubsection{The COMESA SPS Regulations}

The Regulations on the Application of Sanitary and Phytosanitary Measures (the 'COMESA SPS Regulations') were adopted by the COMESA Council and entered into force on $9^{\text {th }}$ December 2009. ${ }^{122}$ The COMESA SPS Regulations adopt the definitions in Annex A of the WTO SPS Agreement unless otherwise required by the context of the agreement. ${ }^{123}$ COMESA SPS Regulations have three main objectives: To set out the principles and create mechanisms for cooperation in the implementation of the SPS measures by member states; the general protection of human or animal life (sanitary measures) or health or plant life or health (phytosanitary measures) from various risks, and to ensure that the application of the SPS measures does not unnecessarily hinder trade in food and agricultural products in the Common Market. ${ }^{124}$ These aims and objectives are similar to the general aims that are sought in the domestic and international regime when striking a balance between free trade and health protection. The Regulations, therefore, just like the WTO SPS Agreement, seek to strike that coveted 'negotiated balance between the competing goals of the liberalisation of trade in the food and agricultural sector and the protection of health by national governments. ${ }^{125}$

In this analysis, it is important to note that all the COMESA member states are either developing states or least developing states. ${ }^{126}$ Therefore, there must be concern about the development dimension on meeting the objectives set out in the COMESA SPS Regulations. Developing and least developing countries bear a huge brunt when it comes to the innocuous application of SPS measures. ${ }^{127}$

On the application of the COMESA Regulations, member states have the right to take SPS measures necessary for the protection of human, animal or plant life or health provided that such measures are not inconsistent with the Regulations. ${ }^{128}$ This provision is a direct borrowing of the language in the WTO SPS Agreement. ${ }^{129}$ The Regulations introduce some of the main substantive commitments in terms of SPS by requiring that member states ensure that SPS measures are only applied to the extent necessary to protect human, animal or plant life or health, and are based on scientific principles and not maintained without sufficient scientific evidence. ${ }^{130}$ Additionally, member states commit to avoid taking any arbitrary or unjustified measures which could result in discrimination or disguised restriction on regional or international trade. ${ }^{131}$ These provisions, however, have the caveat in Regulation 5 on the use of the precautionary principle. There is also a direct transplantation of the language in the WTO SPS Agreement. ${ }^{132}$ This consequently means that the sufficiency of scientific standards required in the WTO SPS Agreement and the exception in the nature of the precautionary principle is applicable under the COMESA SPS Regulations.

122 Regulations on the Application of Sanitary and Phytosanitary Measures, COMESA Legal Notice No. 310 of 2009, Official Gazette, Vol. 15, No. 5, 8 December 2009.

123 COMESA SPS Regulations, Regulation 1.

124 COMESA SPS Regulations, Regulation 2.

125 Paul (2003) 284-340, 339-40.

126 UNCTAD (2017a) link 19; UNCTAD (2017b) link 20.

127 Otsuki, Wilson and Sewadeh (2001) 495; Henson and Rupert (2001) 85.

128 COMESA SPS Regulations, Regulation 4(1).

129 WTO SPS Agreement, Article 2(1).

130 COMESA SPS Regulations, Regulation 4(2).

131 COMESA SPS Regulations, Regulation 4(3).

132 WTO SPS Agreement, Article 2(2) \& 5(7). 
From this, it can been seen that the tool proposed under the WTO SPS Agreement and the COMESA SPS Regulations to distinguish between measures that aim at health protection and those that are a disguised form of protectionism is science. ${ }^{133}$ This principle, as shown here, is embedded in the WTO SPS Agreement. 'The first mention of scientific disciplines in the SPS Agreement is found in the second and third prongs of Article 2.2, which require that SPS measures be based on scientific principles and not be maintained without sufficient scientific evidence, except as provided for in Article 5.7.' 134 Interestingly, the finest example of the imposition of SPS measures not sufficiently based on scientific standards involves a COMESA member state. These are the European Communities' (EC) (now European Union (EU)) measures targeted on Kenyan fish. From 1997 the EC enacted a series of measures against Kenyan fish. 'The measures included new testing requirements and bans as a precautionary response to the outbreak of cholera in Mozambique, Kenya, Uganda, and Tanzania ${ }^{135}$ and due to the EC's suspicion that Kenyan fishermen were using pesticide chemicals to catch fish by poisoning them.' ${ }^{136}$ 'The EC ban was extended for a long period despite the absence of detectable chemical residues in the Kenyan fish exports and the statements by Food and Agriculture Organization (FAO) and the World Health Organization (WHO) that the risk of transmission of cholera from commercially imported fish was negligible. ${ }^{137}$

Additionally, Regulation 6 of the COMESA SPS Regulations provides that member states shall comply with Articles 3 to 8 of the WTO SPS Agreement. This means 'the harmonisation obligation', 'equivalence', 'risk assessment and determination of appropriate of level of sanitary or phytosanitary protection', 'adaptation to regional conditions, including pest or disease free areas and areas of low pest or disease prevalence', 'transparency and control, inspection and approval procedures.' will be applied in the COMESA region. The interpretation offered by the WTO Dispute Settlement Body (DSB) can also be applied in the case of COMESA. The fundamental obligation of basing SPS measures on scientific standards has been underlined in EC-Hormones by the WTO Appellate Body (AB):

'The requirements of a risk assessment under Article 5.1, as well as of 'sufficient scientific evidence' under Article 2.2, are essential for the maintenance of the delicate and carefully negotiated balance in the SPS Agreement between the shared, but sometimes competing, interests of promoting international trade and of protecting the life and health of human beings. '138

The legal implication of the transplantation of the WTO SPS obligations to all COMESA member states is that the multilateral obligations are now made regionally mandatory. This can only be said to be SPS plus when considering that at least five-member states (Comoros, Ethiopia, Libya, Seychelles, Sudan, and Eritrea) of COMESA are not WTO member states. These countries will have multilateral standards apply to them due to their COMESA membership. This is an SPS Plus implication only when considered from

133 Prévost (2009) 587.

134 Prévost (2009) 587.

135 Committee on Sanitary and Phytosanitary Measures (1998).

136 Abila (2003); Henson and Mitullah (2004).

137 Prévost (2009) 588.

138 Appellate Body Report, EC-Hormones, para. 177. 
the vantage point of other WTO membership. The obligations in the COMESA SPS Regulations cannot be applied by other WTO members against the non-WTO members but the fact that the non-WTO members in COMESA are bound by WTO international standards is a huge plus.

Moreover, the COMESA SPS Regulations ${ }^{139}$ also provide an avenue of dealing with the inherent scientific uncertainty in scientific inquiries, just like the WTO SPS Agreement. ${ }^{140}$ This is the now infamous precautionary principle. 'At the core of the precautionary principle lies the notion of scientific uncertainty in situations where action or inaction appears warranted based on the threat of serious or irreversible damage. ${ }^{141}$ Prof Wagner defines the precautionary principle in the following terms:

'The precautionary principle is not applicable in situations where sufficient scientific data is available to make rational decisions in the presence of uncertainty. It is also not supportive of a choice to be more risk averse than implied in an international standard. Rather, if it is to be both meaningful and applicable in the context of international trade, the precautionary principle can only be applicable in situations in which scientific information is not available or not available in sufficient detail in order to make a decision. To put it another way: the precautionary principle is a tool for decision-making in the absence of scientific evidence.' ${ }^{142}$

\subsubsection{The COMESA Green Pass Certification (GPC) Scheme}

The most important innovation of the COMESA SPS Regulations is the establishment of the COMESA Green Pass Certification (GPC) scheme. ${ }^{143}$ This scheme sets the COMESA SPS Regulations as an example SPS-Plus regime. This does not mean that the GPC scheme lacks discrepancies as it is a commodity-specific SPS certification scheme and authority for movement of food and agricultural products within the Common market, issued by a National Green Pass Authority. ${ }^{144}$ The objectives of the Green Pass scheme is twofold: To facilitate movement and trade in food and agricultural commodities; and to protect human, animal, and plant health or life, and the socio-economic structures and institutions of member states. ${ }^{145}$ The incorporation by reference of the SPS definition in Annex A of the WTO Agreement in the COMESA SPS Regulations and the goal and purpose of the Green Pass Certification Scheme (as stated above) means that it can be asserted that the COMESA Green Pass Certification Scheme is intended to be a certification scheme for the combating of unjustified SPS measures that affect international trade among the COMESA member states. Ravelomanantsoa argues that the GPC scheme is intended as a SPS measure ${ }^{146}$ as it would be more accurate to call it a regional SPS measure set to combat the arbitrary imposition of SPS measures that affect international trade.

Additionally, where a member state applies to an authority to issue a Green Pass for a commodity or group of commodities but fails to meet the stipulated requirements for the

139 COMESA SPS Regulations, Regulation 5 (Interim measures).

140 WTO SPS Agreement, Article 5(7).

141 Wagner (2012) 718.

142 Wagner (2012) 720.

143 COMESA SPS Regulations, Regulation 7.

144 COMESA SPS Regulations, Regulation 7.

145 COMESA SPS Regulations, Regulation 8.

146 Ravelomanantsoa (2012) 21. 
commodity or group of commodities, the Secretariat may assist the member state to formulate a programme of interventions and source funds to address the specific deficiencies observed. ${ }^{147}$

An enterprise can be registered under Regulation 10(b) where it satisfies the SPS requirements as required for the commodity in question in the specific Council regulations, directives and codes of practice issued in accordance with Regulation 18. ${ }^{148}$ Regulation 18 has provisions for mutual support and cooperation among member states. ${ }^{149}$

A reading of 'regulations 7, 8, 10, and 12 of the COMESA SPS Regulations show that the GPC Scheme is a SPS measure which would be a sanitary or a phytosanitary certificate issued by a National Green Pass Authority to exclusively registered enterprises for the movement of specified food and other agricultural commodities within the Common Market. ${ }^{150}$ This can be interpreted to be a harmonisation measure in the COMESA region that endeavours to create a single SPS regulatory regime among COMESA member states. The criteria for certification under the GPC scheme are like that of imposition of SPS measures under the WTO agreement due to the similarity of requirements in the COMESA Regulations to the WTO SPS agreement. There must be science-based measures and internationally-recognised standards for commodies and enterprises to be certified. The precautionary principle can also be applied in situations where there is scientific uncertainty.

Finally, there are many inconsistencies of the COMESA Regulations with the WTO SPS agreement that should be highlighted. Paragraph 4 of the COMESA Regulations preamble recognises the crucial harmonising role to be played by international bodies, including the Codex Alimentarius Commission (Codex), the World Organisation for Animal Health (OIE) and relevant international and regional organisations operating within the framework of the International Plant Protection Convention and any other organisation relevant to SPS measures. This is a blanket opening up of the COMESA Regulations, unlike the WTO Agreement, which tasks the SPS Committee with developing procedures to monitor the process of international harmonisation and coordination. ${ }^{151}$ The definitions within the COMESA Regulations omit the last limb of the WTO SPS Agreement on any 'measure applied to prevent or limit other damage within the territory of the Member from the entry, establishment or spread of pests ${ }^{152}$ and replaces it with ensuring the protection of member states 'from the socio-economic structures and institutions of a Member State from

147 COMESA SPS Regulations, Regulation 11(2).

148 COMESA SPS, Regulation 12(1).

149 These includes the harmonisation of national legislation in relation to SPS measures; the development of codes of practice, guidelines and procedures on SPS measures, including procedures for monitoring, surveillance, emergency preparedness, traceability, control, inspection approval, laboratory testing and management, certification and accreditation; the establishment of appropriate coordinating mechanisms amongst recognised national SPS institutions; areas of processing technologies, diagnosis, research and infrastructure, including the establishment and upgrading of national regulatory bodies or national or regional SPS related facilities; training and capacity building at the national and regional levels; the establishment and implementation of the necessary mechanisms for monitoring and surveillance, emergency preparedness and traceability of human food-borne illness and zoonoses, as well as, animal and plant pests and diseases; the establishment of an early warning system to enhance national and regional emergency response capacity and (matters of bio-safety as provided for under the relevant international conventions and protocols.

150 Ravelomanantsoa (2012) 22.

151 WTO SPS Agreement, Article 3(5).

152 WTO SPS Agreement, Annex A. 
risks arising from the entry, establishment and spread of pests and diseases'. ${ }^{153}$ Magalhães argues that this change weakens the COMESA Regulation's protection. ${ }^{154}$ Regulation 5, paragraph 1 of the COMESA Regulations embodies the all-important precautionary principle. It excludes the term 'relevant scientific evidence' used in the WTO SPS Agreement ${ }^{155}$ and instead uses 'sufficient scientific information'. This change of terminology has the potential of dangerously undermining WTO rights and obligations of member states. ${ }^{156}$ Under Regulation 23 of the COMESA Regulations, the dispute resolution process is different from that of the WTO DSB. The regulations do not mention the relationship between the dispute resolution process prescribed in the regulation i.e., consultations, if the consultations fail in 60 days a committee resolution is proffered, where a member is not satisfied with the committee resolution the member can submit the dispute to the COMESA Court of Justice for binding arbitration under Article 28 of the COMESA Treaty, and the WTO DSB process. This omission might cause inconsistencies when it comes to whether the COMESA dispute resolution process takes precedence over the WTO DSB.

\subsection{Comparisons between COMESA-EAC-SADC SPS Annexes}

At a glance, the COMESA, EAC and SADC Instruments on SPS measures are complimentary as they each have the objective of regulating SPS. Each Instrument seeks to strike a balance between the protection of plant, animal and human health or life while at the same time pursuing the objective of trade liberalization. However, a close examination reveals that there are challenges and opportunities that must be explored particularly in the process of gearing up towards that TFTA and eventually the CFTA. ${ }^{157}$

One of the main challenges is to avoid overlap, duplication and contradiction in relation to the WTO SPS Agreement and SPS regimes of the different RECs. COMESA, EAC, and SADC SPS regimes are based on the text of the WTO SPS Agreement and draw considerably from the text of the Agreement. ${ }^{158}$ This practice of repeating, restating in part, and rephrasing selected parts of the texts of the WTO SPS Agreement leads to a situation where important rules and safeguards contained in WTO Agreements are amended or omitted. ${ }^{159}$ As a result, there is a risk of overlap and even contradiction with the WTO SPS Agreement, thereby limiting the rights and obligations of members under one instrument. ${ }^{160}$ The SADC SPS regime, for example, fails to address key notions of the SPS Agreement such as non-discrimination, non-arbitrariness and disguised restrictions on trade whilst the EAC SPS regime does address some of these notions. ${ }^{161}$

There is also a risk of duplication, overlap and contradiction amongst the different RECs which arises because most States are members of more than one REC. Kenya for example, is a member of the EAC and COMESA while Tanzania is a member for both EAC and SADC. The confusion is further compounded by the fact that each of these

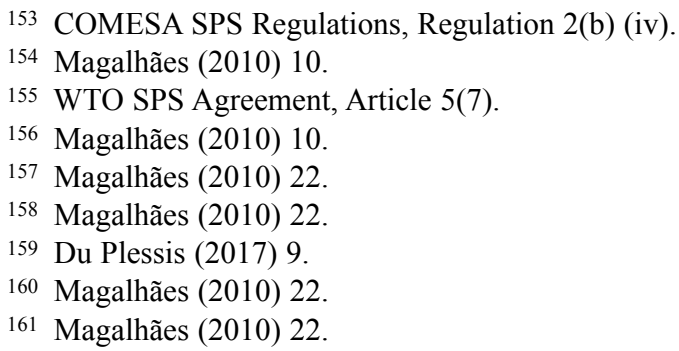


RECs, in an attempt to mirror the WTO SPS Agreement, may arrive at different obligations. ${ }^{162}$ The most evident example is on the provisions on dispute settlement with each RECs having provisions on disputes settlement and as well as the WTO SPS Agreement. Therefore, in the event of a dispute, it may be unclear as to which forum a state is required to approach and whether their rights are limited after seeking relief in one of the forums.

Another issue arises in regard to the aims and objectives of the different Agreements. Each of the RECs has its own SPS regime and each Agreement states aims and objectives of the Agreement. In COMESA, the objectives are provided for under Regulation 2, ${ }^{163}$ in EAC under Article $2^{164}$ and in SADC Article 3 provides for the objectives of the SADC SPS Annex. ${ }^{165}$ This gives rise to uncertainty particularly when it comes to harmonisation particularly because such clauses have previously yielded widely varying results. ${ }^{166}$

The relationship between voluntary and mandatory measures is ambiguous among the different RECs as they are not discussed in sufficient detail in some of the RECs. ${ }^{167}$

Positive attributes include additions outside the scope of the WTO SPS Agreement good regulatory practice, active elimination of unjustified SPS measures or regional harmonisation are in order if they clearly have the objective of improving regional integration and boosting intra-African trade. ${ }^{168}$

\section{SPS MEASURES UNDER THE TRIPARTITE FREE TRADE AGREEMENT (TFTA)}

The first part of this paper has shown that the TFTA has 27 projected member states and by $7^{\text {th }}$ July 2017, a total of 19 countries had signed Tripartite Agreement at the ministerial meeting in Kampala. ${ }^{169}$ At the time of writing, the TFTA Agreement in Article 22 provides for sanitary and phytosanitary measures (SPS). The member states agree on this provision to reaffirm their rights and obligations in respect of the WTO SPS Agreement. ${ }^{170}$ This is an important commitment by the TFTA members, especially the TFTA members such as Comoros, Ethiopia, Eritrea, Libya, Sudan, and South Sudan who are not WTO members. These countries are to be held to a multilateral standard through a regional scheme. This is accordingly an SPS-Plus commitment at least for such countries. Article 22 proceeds to provide that the member states shall undertake to facilitate safe trade in animals and animal products, plants and plant products whilst safeguarding human, animal and plant life or health. ${ }^{171}$ This provision is only a general obligation for the member states but should be attractive to other states not part of the TFTA. This is a direct corollary of having a robust protection system at the TFTA level. Furthermore, Article 22 requires that member states cooperate to eliminate unjustifiable SPS measures to facilitate safe trade in sectors of

162 Magalhães (2010) 22.

163 COMESA SPS Regulations, Regulation 2.

164 East African Community Sanitary and Phytosanitary Measures Protocol (2013) Article 2.

165 SADC SPS Annex, Article 3.

166 Du Plessis (2017) 9.

167 Du Plessis (2017) 10.

168 Du Plessis (2017) 11.

169 TRALAC (2017) link 18.

170 Tripartite Free Trade Agreement, Article 22(1).

171 Tripartite Free Trade Agreement, Article 22(2). 
mutual economic interest. ${ }^{172}$ The provision finally, establishes a capacity building programme and indicates that the implementation of the provision would be according to the relevant annex. ${ }^{173}$

\subsection{Annex 15 of the African TFTA on SPS measures}

At the onset, it is important to mention that the draft annexes of the TFTA have been undergoing negotiation in the past years. This means that the final annex that deals with SPS measures might end up as a different annex once the final instrument is released. This notwithstanding, Annex 15 is referred to in this article as the most current draft. The SPS annex of the TFTA as it stands is an awful case of SPS-Minus provisions of the WTO SPS Agreement and the SPS obligations in the three specific RECs it constitutes; SADC, EAC, and COMESA. The annex has a paltry seven provisions, inadequate, by any standards, of the kind of objectives the TFTA seeks to achieve. It does not incorporate the progressive provisions in SADC, EAC, and COMESA discussed in the previous part either directly or by indirect reference. It is as if the TFTA was being negotiated on a tabula rasa. This is undesirable for the objective of progressively eliminating tariffs and nontariff barriers (NTBs) to trade that the TFTA aims at achieving. ${ }^{174}$ Additionally, it takes the regionalism advancement in Africa backwards as the desire of having a WTO consistent FTA cannot be achieved. This is because 'duties and other restrictive regulations of commerce (will not be) eliminated on substantially all the trade between the constituent territories in products originating in such territories.' ${ }^{\prime 75}$

Some of the states under the TFTA are also members of the WTO. This means that the multilateral obligations stemming from the WTO SPS Agreement will apply to them even without the obligations in the TFTA-SPS Annex. The core substantive provisions of the TFTASPS Annex are largely identical in wording and in purpose to those of the WTO SPS Agreement. There are, however, certain specific provisions that are lacking or not as elaborative in the TFTA-SPS Annex and this may lead to serious legal implications.

The first implication is that the principle of harmonisation is one of the key provisions missing from the TFTA-SPS Annex. The WTO SPS Agreement requires that members 'base their sanitary or phytosanitary measures on international standards, guidelines, and recommendations.' This provision was included as the negotiators of the SPS Agreement aimed to reduce unnecessary trade impacts of national SPS measures by promoting greater convergence of the risk regulatory requirements applied by members. One would think that one of the aims of the TFTA-SPS Annex would be to reduce unnecessary trade impacts of RECs SPS measures, but it seems it was not.

Another implication is that members of WTO, trading in the same product, are required to accept sanitary and phytosanitary measures of other members as equivalent. This is the embodiment of the principle of equivalence. The exporting member needs to objectively demonstrate to the importing member that its measures achieve the importing member's appropriate level of sanitary and phytosanitary protection. The WTO SPS Agreement does not require 'duplication or sameness' of the measures, but 'the alternative' of the

172 Tripartite Free Trade Agreement, Article 22(3).

173 Tripartite Free Trade Agreement, Article 22(4); 22(5).

174 Tripartite Free Trade Agreement, Article 5(a).

175 GATT 1995, Article XXIV (8) (b). 
measure if objectively and scientifically proven should be acceptable. By failing to include this obligation, TFTA member states that are neither WTO members nor COMESA members may find themselves without the obligation of equivalence. Even though it may be argued that this obligation can be traced in the other RECs' obligations, an inclusion in the TFTASPS annex would settle the issue once and for all.

A significant omission is that the TFTA-SPS Annex lacks provisions on risk assessment and determination of the appropriate level of SPS protection. Contrastingly, the WTO SPS Agreement requires members to base their SPS measures on relevant scientific evidence as described in Articles 2 and 5 of the WTO SPS Agreement. WTO members are required to base their SPS measures, on an assessment and as appropriate to the circumstance of the risk to human, animal and plant life or health. This was introduced as harmonisation would not be feasible in all cases. Where members' SPS measures cannot be harmonised because no international standard exists, or some members opt for more stringent regulations, the SPS Agreement requires that such national measures have a scientific basis. Thus, science plays an important role in establishing the boundaries of permissible SPS risk regulation. A member introducing SPS measures is required to bring forward scientific evidence which supports the existence of a threat and is specific to the risk of concern. On what basis will the TFTA member states base their measures on and how will they justify the measures? Could this lead to imposition of SPS measures that will only be barriers to trade? Even with the specific SPS on the RECs it is difficult to see how such an important obligation would be absent from the TFTA-SPS annex.

Furthermore, the precautionary principle is only incorporated in the WTO-SPS Agreement. Member states as stated earlier, can depart from the structures of risk assessment. Such a member state must determine that the available relevant scientific evidence or other information is insufficient to complete the assessment. The member state may then adopt a provisional SPS measure on the basis of available relevant information including international standardising organisations and SPS measures of other member states. Applying precautionary measures for a temporary period is considered part of the risk management. Upon additional information being obtained for a more objective risk assessment, members are required to review the measures. The discretion member states have to impose precautionary measures may result into either legitimate trade restrictions or abuse by states. The Author would venture to argue that perhaps this is the reason why it was left out in the TFTA-SPS Annex. It is, however, important to note that the precautionary principle has become so intertwined to most SPS-Plus regional obligations that it is difficult to fathom that it would be excluded from the TFTA-SPS regime.

Finally, the WTO SPS Agreement provides for special and differential treatment in favour of developing countries and least-developed countries. Special and differential treatment as seen before is a principle that seeks to consider the unique needs of developing and least developing countries, granting them favourable treatment in trade so as to increase their capacity to participate in the global trading system. The TFTA-SPS Annex, unlike the WTO SPS Agreement, but similarly to the SADC, EAC, and COMESA SPS regimes has no provisions on special and differential treatment. This could be, as previously argued, due to the fact that the TFTA covers African most if not all are developing or least developed countries.

The annex does not take into account the positive provisions in the three RECs it seeks to amalgamate into one single FTA. If the provisions of the SADC, EAC, and COMESA are anything to go by, the TFTA annex is a far cry from what would have been expected 
were the provisions in the three RECs to be merged through a process of systemic harmonisation. Specifically, The TFTA in Annex 15 is a case of SPS-Minus because of number of serious shortcomings: lack of important obligations on sufficient risk assessment, non-discrimination, equivalence, the principle of precaution, and specific reference to consultations and dispute settlement. The drafters of the annex did not take into account the progressive provisions set out in the SADC protocol and its Annex VIII, the EAC SPS Protocol, and the COMESA SPS Regulations. With these shortcomings in mind and the problem of multiple and overlapping memberships in the current RECs terrain in Africa still present, it can be easily seen why the author reaches the inevitable conclusion that the TFTA SPS regime is SPS-minus.

\section{CONCLUSIONS}

NTBs generally and unjustified SPS measures specifically remain a serious threat to the liberalisation of trade in Africa. Most Sub-Saharan African (SSA) countries are dependent on agricultural trade as a focal point of their export earnings so the process of identification, monitoring and elimination of unjustified SPS measures is important in both intra and extra African trade. The difficulties encountered by SSA countries in effective participation in the WTO have had an impact on how developed nations have been able to use SPS measures for protectionist purposes. The best way to address this is greater capacity building among SSA countries with assistance from developed nations.

This article has analysed the SPS measures under three different RECs: SADC, EAC, and COMESA. This was followed by an assessment of the TFTA-SPS measures and found that important obligations on risk assessment, harmonisation, and equivalence have been left out. This omission will have far reaching implications on the liberalization generally, and the elimination of NTBs in intra and extra African trade. These shortcomings, the Tripartite Free Trade Area (TFTA) has the potential for great achievement in the curbing of NTBs generally and unjustified SPS measures specifically if stronger measures on monitoring, transparency, and harmonization obligations are enhanced. The process of regionalism in Africa has made it difficult to deal with unjustified SPS standards as African states are members of different RECs which have intertwining standards creating a 'spaghetti bowl.' The augmentation of some of the mechanisms for the identification, monitoring, and elimination of NTBs is highly welcome. The COMESA-EAC-SADC Tripartite mandate is a good example of how this process has begun in Africa. A lot, however, remains to be done to foster free trade in Africa that has the potential of eradicating poverty through wealth and employment creation.

\section{LITERATURE}

Abila, Richard O., Food Safety in Food Security and Food Trade. Case Study: Kenyan Fish Exports (International Food Policy Research Institute, Washington D.C., September 2003).

Santana, Roy and Jackson, Lee, 'Identifying Non-Tariff Barriers: Evolution of Multilateral Instruments and Evidence from the Disputes (1948-2011)' (2012) 11:3 World Trade Review 462-78.

Alemanno, Alberto, Trade in Food: Regulatory and Judicial Approaches in the EC and the WTO (Cameron May Ltd 2007).

Brennan, Anna, 'The special and differential treatment mechanism and the WTO: Cultivating trade inequality for developing countries?'(2011) 14 Trinity College Law Review 139-51.

Committee on Sanitary and Phytosanitary Measures (1998) Measures in Response to Cholera. Statement by the European Community at the Meeting on 12 and 13 March 1998, G/SPS/GEN/68, circulated on 18 March 1998. 
Decision on the Implementation of Article 4 by the SPS Committee called 'Decision on Equivalence'. This was adopted by the SPS Committee in 2001 and was revised in 2002, 2003, and 2004.WTO Doc G/SPS/19/Rev. 2 (23 July 2004).

Du Plessis, Abrie, 'The Sanitary and Phytosanitary (SPS) policies of the African Regional Economic Communities (RECs), and the way forward for the Continental Free Trade Area' (2017) Trade Law Centre 9-11.

Gathii, James, 'African Regional Trade Agreements as Flexible Regimes' (2010) 3 North Carolina Journal of International Law 571-668.

Gathii, James, Designing the Continental Free Trade Area (CFTA): An African Human Rights Perspective (UN Human Rights Office of the High Commissioner, UN Economic Commission for Africa [UNECA], Friedrich Ebert Stiftung 2016).

Gebrehwet, Yemani, Ngqangweni, Simphiwe and Kirsten, Johann, 'Quantifying the Trade Effects of Sanitary and Phytosanitary Regulation of OECD Countries on South African Exports' (2007) 1 Aggrekon 23-39.

Guzman, Andrew and Pauwelyn, Joost, International Trade Law (2ed, Aspen Publishers 2012).

Helfer, Laurence, 'Flexibility in International Agreements' in Dunoff, Jeffrey and Pollack, Mark A. (eds), International law and International Relations: Taking Stock (Cambridge University Press, 2012) 175-93.

Implementation of special and differential treatment provisions in WTO Agreements and Decisions, Mandatory and non-mandatory special and differential treatment provisions, Note by the Secretariat, Committee on Trade and Development, WT/COMTD/W/77/Rev.1/Add.1, 21 December 2001.

Joubert, Biandri, Sanitary and Pytosanitary Measures in the SADC Region: A South African Legal Perspective (Mini LLM Dissertation, North-West University 2014).

Kalenga, Paul 'Implementation of the SADC Trade Protocol: A Preliminary Review' in Hansohm, Dirk et al (eds), Monitoring Regional Integration in Southern Africa Yearbook (Namibian Economic Policy Research Unit and the Konrad-Adenauer-Stiftung 2004), 17-33.

Landwehr, Oliver, 'Article 4 SPS', in Wolfrum Rudiger, Stoll Peter-Tobias, and Seibert-Fohr Anja (eds), WTO Technical Barriers and SPS Measures (Martinus Nijhoff, 2007), 433-52.

Laowonsiri, Akawat, 'Application of Precautionary Principle in the SPS Agreement' (2010), 14 Max Planck Yearbook of United Nations Law 567-623.

Marceau, Gabrielle and Trachtman, Joel, 'The Technical barriers to Trade Agreement, the Sanitary and Phytosanitary measure Agreement, and the General Agreement on Tariffs and Trade: A Map of the World Trade Organization Law of Domestic Regulation of goods' (2002) 36:5 Journal of World Trade 811-81.

Magalhães, João, Regional Sanitary and Phytosanitary Frameworks and strategies in Africa Report for the Standards and Trade Development Facility (STDF 2010).

Magalhães, João, Report for the Standards and Trade Development Facility (STDF), July 2010.

Nic Shuibhne, Niamh, Regulating the Internal Market (Edward Elgar Publishing Limited 2006).

Osiemo, Onsando, 'The Last Frontier: Sanitary and Phytosanitary Standards and Technical Regulations as Non-Tariff Barriers in Intra-African Trade' (2015) 1 African Journal of International and Comparative Law 165-89.

Paul, Joel, 'Do International Trade Institutions Contribute to Economic Growth and Development?' (2003) 1 Virginia Journal of International Law 284-340.

Pauwelyn, Joost, 'The Transformation of World Trade' (2005) 1 Michigan Law Review, 641-64.

Pauwelyn, Joost, 'The WTO Agreement on Sanitary and Phytosanitary (SPS) Measurers as applied in the first three SPS disputes: EC-Hormones' (1999) Journal of International Economic Law $630-51$.

Prévost, Denise, Balancing Trade and Health in the SPS Agreement: The Development Dimension (Nijmegen: The Netherlands, Wolf Legal Publishers, 2009).

Prévost, Denise, 'Sanitary, Phytosanitary and Technical Barriers to Trade in the Economic Partnership Agreements between the European Union and the ACP Countries - ICTSD Programme on EPAs and Regionalism' (2010) 6 Institute for Globalisation and International Regulation, Issue paper. $<$ https://www.carib-export.com/obic/documents/prevost_web_final.pdf $>$ accessed 30 November 2017. 
Ravelomanantsoa, Lalaina, 'Legal Study on the Regulations on the Application of Sanitary and Phytosanitary Measures of the Common Market for Eastern and Southern Africa The National Legal Implications of the COMESA Green Pass Certification Scheme' (2012) Food and Agriculture Organization of the United Nations. <http://www.standardsfacility.org/sites/default/ files/STDF_PPG 346_FinalLegalStudy_Jun-12.pdf> accessed 30 November 2017

Van den Bossche, Peter, The Law and Policy of the World Trade Organization: Text, Cases and Material (Cambridge University Press, 2013).

Wagner, Markus, 'Taking interdependence seriously: The need for a reassessment of the Precautionary Principe in international trade law' (2012) 20 Cardozo Journal of International \& Comparative Law 713-69.

Wagner, Markus, 'The future of Sanitary and Phytosanitary Governance: SPS-Plus or SPS-Minus' (2017) 3 World Trade Review 445-70.

\section{LINKS}

1. Classification of non-tariff measures 3, United Nations Conference on Trade and Development (UNCTAD) (2012) <http://unctad.org/en/PublicationsLibrary/ditctab20122_en.pdf > accessed 14 October 2015.

2. Juma, Mageni (2017) Juma, Calestous and Mageni, Francis 'The Benefits of Africa's New Free Trade Area' (2017) <https://www.belfercenter.org/publication/benefits-africas-new-freetrade-area- $0>$ accessed 31 October 2017.

3. Eatradehub $(2016)<\mathrm{http}: / /$ www.eatradehub.org/kenya_ratifies_the_eac_sps_protocol $>$ accessed 01 July 2016.

4. COMESA (2017) 'COMESA Member States'<http://www.comesa.int/comesa-members-states> accessed 14 October 2015.

5. COMESA-EAC-SADC, Non-Tariff Barriers: Reporting, Monitoring and Eliminating Mechanism (2017) <http://www.tradebarriers.org/about> accessed 25 November 2015.

6. EAST AFRICAN COMMUNITY, COMESA-EAC-SADC Tripartite (2017) <http://www.eac.int/ index.php?option=com_content\&id=1496\&Itemid=201 $>$ accessed 23 November 2017.

7. East Africa Trade and Investment Hub (2016) East Africa Trade And Investment Hub, Improving Trade With Appropriate Sanitary Phytosanitary Measures $<\mathrm{https}$ ://thehub.exposure.co/improvingtrade-with-appropriate-sanitary-phytosanitary-measures $>$ accessed 14 October 2017.

8. Elizabeth Nderitu, EAC Act on Non-Tariff Barriers a Boon to Regional Trade (2017) $<\mathrm{http}: / /$ www.theeastafrican.co.ke/OpEd/comment/EAC-Act-on-non-tariff-barriers-a-boon-to-regionaltrade-/-/434750/2718908/-/vgnnbjz/-/index.html> accessed 14 October 2015.

9. Kalenga, Paul. 'SADC Annual Conference' 7-9 September (2011)<www.tralac.org $>$ accessed 10 October 2011.

10. Kenya's Ratification $(2016)<\mathrm{http}: / /$ www.eatradehub.org/kenya_ratifies_the_eac_sps_protocol> accessed 30 November 2017.

11. Bird (2017) Bird, Mike 'Africa is about to launch a Cairo-to-ape Town Free Trade Area that's bigger than the European $<$ http://www.businessinsider.com/africa-is-about-to-launch-a-cairo-tocape-town-free-trade-area-thats-bigger-than-the-european-union-2015-5?IR=T\#ixzz3cP1wnsRI> accessed 31 October 2017.

12. Pascal Lamy, WTO Director General Farewell Statement to the General Council on Jul. 2013, WTO NEWS ITEMS (2013) <http://www.wto.org/english/news_e/ge_rpt_24jul13_e.htm> accessed 14 October 2015.

13. Paul Kalenga, 'Implementation of the SADC Trade Protocol: A Preliminary Review' in Dirk Hansohm et al (eds), Monitoring Regional Integration in Southern Africa Yearbook Namibian Economic Policy Research Unit and the Konrad-Adenauer-Stiftung (2004) <http://www.kas.de/ wf/doc/kas_16110-1522-1-30.pdf?110125181323> accessed 25 November 2017.

14. Protocol on the Establishment of the East African Customs Union (2005) <http://eacgermany.org/ wp-content/uploads/2014/10/EACCustomsUnionProtocol.pdf $>$ accessed 14 October 2015.

15. SADC (2017) 'Documents \& Publications' <http://www.sadc.int/documents-publications/show/ Protocol_on_Trade1996.pdf $>$ accessed 1 November 2017. 
16. SADC, COMESA, EAC-SADC Tripartite Free Trade Area Launched (2017) <http://www.sadc. int/news-events/news/comesa-eac-sadc-tripartite-free-trade-area-launched/> accessed 14 January 2018.

17. TradeMark East Africa, Africa' Largest Trading Block Resolves 385 Non-Tariff Barriers (2017) $<$ https://www.trademarkea.com/news/africas-largest-trading-block-resolves-385-non-tariffbarriers/> accessed 25 November 2015.

18. TRALAC (2017) <https://www.tralac.org/news/article/11860-the-tripartite-free-trade-area-abreakthrough-in-july-2017-as-south-africa-signs-the-tripartite-agreement.html> accessed 14 October 2015.

19. UNCTAD (2017a) <http://unctad.org/en/Pages/ALDC/Least\%20Developed\%20Countries/UNlist-of-Least-Developed-Countries.aspx $>$ accessed 10 January 2018.

20. UNCTAD (2017b) <http://www.un.org/en/development/desa/policy/wesp/wesp_current/2012 country_class.pdf $>$ accessed on 10 January 2018.

21. Gathii (2017b) UN Human Rights Office of the High Commissioner $<$ http://www.fesglobalization. org/geneva/documents/2016/2016_05_HRIA\%20of\%20the\%20CFTA_Publication.pdf $>$ accessed 14 October 2015.

22. WTO (2017) 'Members and observers' <https://www.wto.org/english/thewto_e/whatis_e/tif_e/ org6_e.htm> Treaty establishing the Common Market for Eastern \& Southern Africa 33 ILM 1067 (1994) (COMESA Treaty) accessed 14 October 2015. 